\title{
BEHAVIOUR AND ECOLOGICAL IMPACTS OF TERMITES: FECUNDITY INVESTIGATIONS IN MOUNDS
}

\author{
SUTUMA EDESSA WAKO
}

Department of Biology Education, Addis Ababa University, P.O. Box 6767, Addis Ababa, Ethiopia; e-mail: sutuma2002@yahoo.com

\begin{abstract}
Wako S.E.: Behaviour and ecological impacts of termites: fecundity investigations in mounds. Ekológia (Bratislava), Vol. 34, No. 1, p. 72-81, 2015.

A radical study was conducted on the behaviour and ecological impacts of termites in Haru District of Western Oromia, Ethiopia. It was aimed at investigating the natural behaviour, fecundity in mounds, ecological impacts and recommending possible solutions to termite problems. Four mounds in different sites were vertically dug down to display the profile of the queen, soldiers, workers, number of laid eggs, nymphs and colonies of termites. On an average, termite queens of the study site may lay about 25 eggs per minute, 36,000 eggs per day and 13,140,000 eggs annually. The fourth queen was unearthed to study the structure, size, number of ovaries and fecundity. It was examined that the death of a queen does not affect the colony, because four small queens are formed and one of them becomes the queen of queens and replaced the dead queen promptly. Accordingly, termites are found to be one of the most destructive agents of our ecosystems and their management requests careful and biological control methods. As a result, the negative effect of termites outweighs the positive effect of termites so that minimising the population size is important for human beings.
\end{abstract}

Key words: alates, cast, colony, queen, red ants and royal cell.

\section{Introduction}

The word termite is of a Greek origin (Greek, tarmes = wood boring worms) given to any of the order of Isoptera (Greek, iso = same and pteron = wing, referring to the similar appearance of all four wings) of pale coloured insects having a soft body, live in colonies and damage wooden structures by gnawing.

Engel and Krishna (2004) classified termites based on food source behaviour and summarised into parts of the Animalia kingdom, Arthropoda phylum, Insecta class, Isoptera order and split into six families: (1) Hodotermitidae (damp wood termites), (2) Kalotermitidae (dry wood termites), (3) Mastotermitidae, (4) Rhinotermitidae (subterranean termites), (5) Termitidae and (6) Termopsidae.

Termites of the order Isoptera are very soft-bodied usually light in color and small- to medium-sized insects that live in social groups or colonies and are characterised by their highly developed caste system (Donovan et al., 2000). 
According to Eggleton (2000), as social insects, termites live in colonies at maturity number from several hundred to several million individual castes, including reproductive females and males, sterile workers and soldiers that commonly contain members of both sexes in equal numbers of males and females, each developed from fertilised eggs; having two pairs of membranous wings, nearly equal in size that break along a suture when shed, leaving only the wing base or scale attached to the thorax, which is the most distinguishable characteristic of isopteran termites.

Body structure of termites consists of a thorax joined broadly to the abdomen without the waist characteristic like bees, ants and wasps (Grimaldi, Engel, 2005). Behaviourally, termites are prime examples in using decentralised and self-organised social life systems through swarm intelligence and cooperation to exploit food sources and environments that could not be available to any single insect acting alone. A typical colony of termites contains nymph alates (semimature young), workers (pale-coloured heads), soldiers (red-coloured heads) and reproductive individuals of both sexes, containing several egg-laying queens. Eggleton and Tayasu (2001) explain that termites have social complex structures of workers, soldiers and alates beside the queen and the king with complex mutualism within guts and fungus farming groups.

Termites prefer to feed on dead plant materials in the form of wood, leaf litter or soil, buildings, crops or plantation and forests using their mouth parts modified for chewing. They damage buildings, flooring, carpeting, art work, books, clothing, furniture and valuable papers. Subterranean termites are ground-inhabiting social insects living in colonies and feed on dead parts of trees but are not known to attack live trees (Eggleton, Tayasu, 2001). Termites are commonly grouped in accordance with their feeding behaviour like subterranean, soil feedings, dry woods, damp woods and grass eating, of which subterranean and dry woods are primarily responsible for damage to human-made structures (Hunt, Nalepa, 1995). Termites are weak and relatively fragile insects that need to stay moist to survive and if not, can be over powered by ants and other predators when exposed. In reaction to enemies, they protect perils by covering their trails with tubing made of feces, plant matter, saliva and soil, nests and mounds to remain hidden and wall out unfavourable environmental conditions.

Out of 4000 species of termites estimated to exist on earth, about 2600 recognised species cause economically serious structural damage to buildings, crops or plantation, forests and also eat bones and carcasses. Although termites are soft-bodied insects, their hard, saw-toothed jaws work like shears and are able to bite off extremely small fragments of wood and some species destroy all live plants within a short period of time causing heavy ecological impact by removing vegetation cover (Ulrich, Nicole, 2002).

Becker (1976) explained that all termites eat cellulose in various forms as a plant fiber, which is a rich energy source, but remains difficult to digest so that they have symbiotic bacteria in their digestive system, which enhances them in decomposing cellulose into carbohydrates and sugar. Carpenter (1967) stated that the intestine of large species of termites feeding on wood (Zootermopsis angusticollis, Hagen, 1858) contains four different flagellated protozoa that assist digestion. Termites rely primarily upon symbiotic protozoa and other microbes in their gut to digest the cellulose and absorb the end products, whereas gut protozoa in turn rely on symbiotic bacteria embedded on their surfaces to produce some of the necessary digestive enzymes (Eggleton, Taysu, 2001). 
Geographically, termites are mostly limited to the tropical and subtropical ecosystems, roughly found between $50^{\circ}$ north and south with the greatest biomass, diversity in tropical forests and Mediterranean scrublands (Emerson, 1952). Vagner (1987) states that among existing termite species of the world, about 600 species (example: Hodotermes mossambicus Hagen, 1858) are found only in Africa. Termites build up different sizes and structures of mounds and nests to house the entire colony. Ground termites usually build mounds with various sculptures, whereas arboreal termites construct nests on trees that provide a protected living space and water conservation through controlled condensation, in which nursery chambers exist deep in the nest where eggs and in-star larvae are tended. The structure of mounds is reasonably complex that the thin end of it faces towards the sun at its peak intensity allows termites to stay above ground, where other species are forced to move deeper into below ground areas. The column of hot air rising in the above ground mounds helps to drive air circulation currents

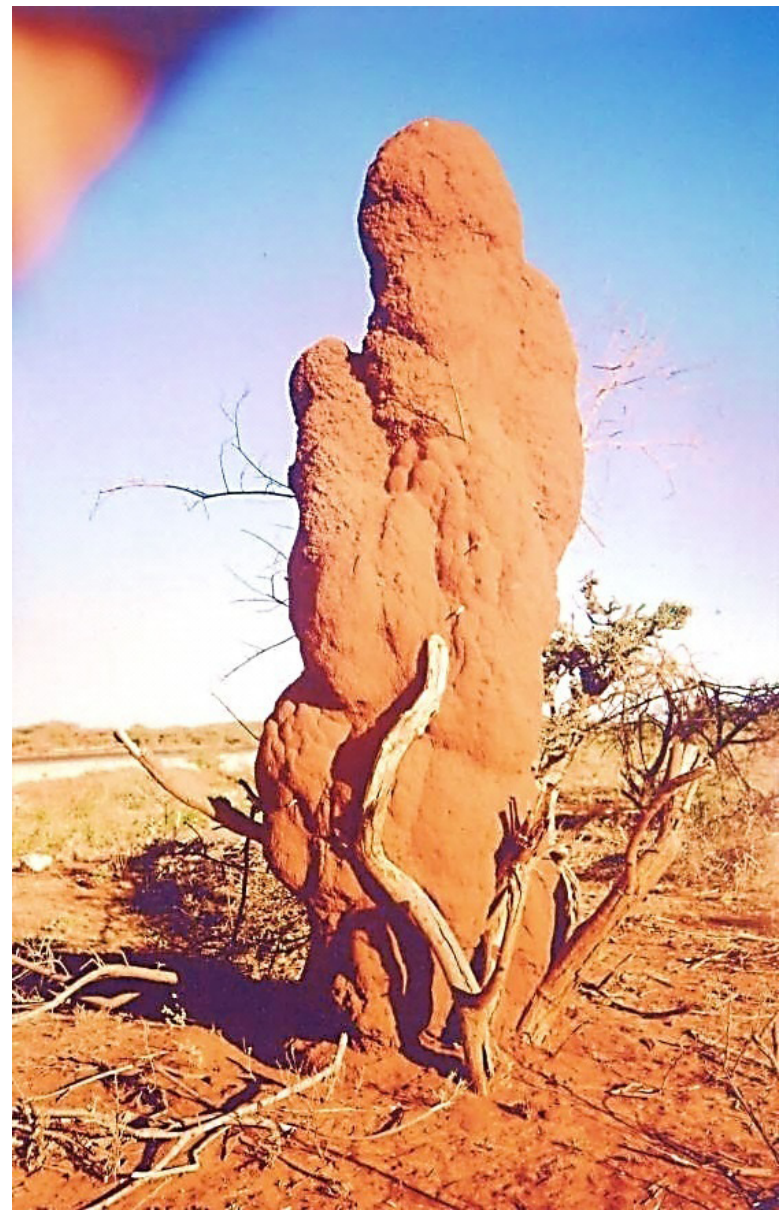

Fig. 1. Termites Mound (Photo by Sutuma Edessa). inside the subterranean network to distribute required temperature for those species cultivating fungal gardens and even for those spending much energy in maintaining the brood within a narrow temperature range $\left( \pm 1{ }^{\circ} \mathrm{C}\right)$ over day (Ulrich, Nicole, 2002).

In tropical savannas, the mounds may be very large with an extreme of $9 \mathrm{~m}$ high like the conical mounds constructed by some species in well-wooded areas or 2-3 $\mathrm{m}$ would be a typical size, whereas the shapes range from somewhat amorphous domes or cones usually covered in grass and/or woody shrubs to sculptured hard earth mounds or a mixture of the two. In some parts of the African savanna or scattered wood lands, high densities of above ground mounds dominate across the landscape including small mounds of about $1-1.5 \mathrm{~m}$ in diameter with a density of about $50-55$ per hectare on grasslands between larger trees in the study site. In southern and eastern parts of Ethiopia (Oromia and Somalia), termites construct 
mound towers ranging 6-9 $\mathrm{m}$ with various types and several stairs, cavities and very long network passages in architectural styles of mounds in scattered woody perennial lowland areas (Fig. 1). The cavity of the colony of the subterranean termites may range from 6 to $7 \mathrm{~m}$ deep into the ground to protect termites from extreme weather conditions, wildfire and calamities so that termites travel through earthen (mud) tubes to reach food sources.

In a mound, a colony reaches its maximum size in approximately $4-5$ years and one may include 60,000 to 200,000 workers, from which winged males and females from a parent colony emerge in flight or swarm with dark brown to brownish black and having two pairs of equal size wings extending well beyond the body (Eggleton, 2000). The process of feeding of one colony member by another is one of the keys to the success in termites (Breznak, Brune, 1994).

Termites are cellulose eating and destructive agents using their population size, so that the study of laid eggs per queen indicates how much they affect the environment in their life cycle. Nonetheless, the study of the isopteran termites to investigate the behaviour, fecundity (reproduction capacity per queen) determines their ecological impacts that require recommendation of possible solutions.

\section{Material and methods}

Innumerable species of termites are widely spread across the country and cause damages on properties and environment at any angle, so that the study was conducted in Haru District of Oromia, Western Ethiopia for three consecutive years.

\section{Materials}

Termites mainly live covered under the ground or diffusively spread in pertinent conditions in accordance with behaviour of each species and relations to food sources. Tools employed for the research activities are microscope, spade, mattock, measuring meter, plastic box and bottles, wooden box with inbuilt chamber for the queen, tweezers, plastic spatula, hand lenses, plastic sheets, digital watch and crucible tongues and the like (Fig. 2).

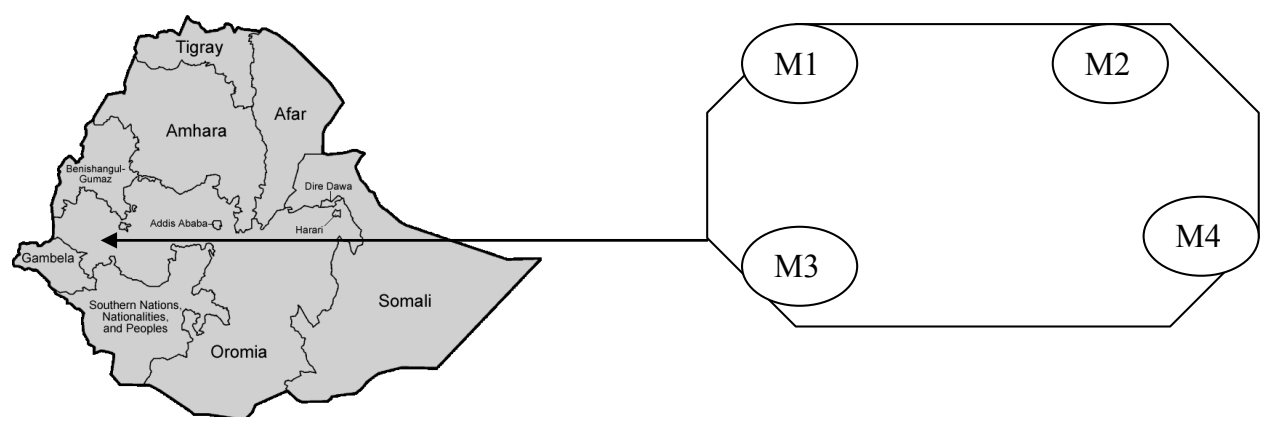

Fig. 2. The study site map and Mounds.

\section{Methods}

Four different sizes of mounds in different localities (M1, M2, M3 and M4) were identified, selected and their above ground height and width were measured to unearth and investigate secrecies covered under each mound. Each mound was dug vertically down to the earth, profiles were displayed, structures and systems of the mound uncovered, termites and queens were seen lay bare with adult males. 
The vertical cutting of the mound unearthed the whole profile, enabled to collect necessary data on the behaviour and life cycle of termites, find out several queens laying eggs, the number of queens existing per mound, labour division among termites and to count and calculate the number of eggs laid by a queen per minute, a day and annually (Table 1).

Generally, in each mound, eggs laid by selected queens per minute were counted, calculated and recorded for three consecutive days at 08:00, 12:00 and 16:00 h. Unlikely, mound four (M4) was used for a reference for study of the structure, size and fecundity of the queen by dissecting the body and observe the inner part using a special hand lens and later a microscope.

M1 is somewhat bulky in size with $1.36 \mathrm{~m}$ in height. It was dug down vertically to the earth to find out new information on the entire termites colony. While digging the mound, it was observed that termites were annoyed and diffusively rushed to find strong protection for the colony, particularly for the queen. Several queens were found at different depths of the mound with slim adult males (the kings) lying next to it in a small chamber. For the purpose of the research, one of the queens found at $3 \mathrm{~m}$ depth under the mound laying eggs in a royal cell (Fig. 3 ) was randomly selected for laid eggs calculation.

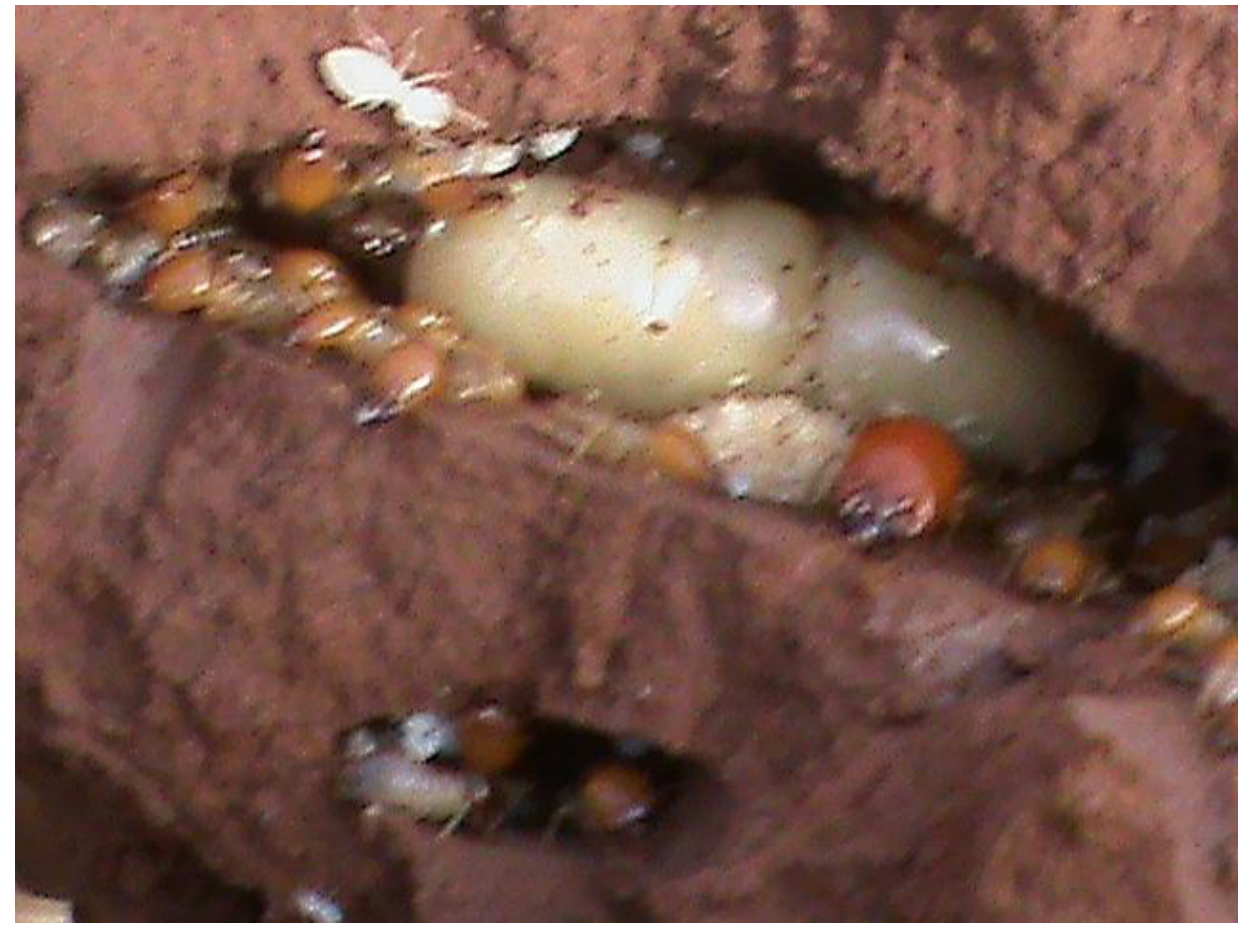

Fig. 3. A queen laying eggs in a royal cell (Photo by Sutuma Edessa).

The second mound (M2) was flattened at the base and cony triangular shape with $1.72 \mathrm{~m}$ in height. It was dug vertically using analogous approaches to collect existing data on termites' colony. In M2, three queens were found in three separated royal cells with an adult male each, which were surrounded by watching soldiers at 2 to $3 \mathrm{~m}$ deep below the mound stairs. Among three queens found, only one queen found at $3 \mathrm{~m}$ depth was selected for counting and calculating laid eggs.

The third mound (M3) was $2.3 \mathrm{~m}$ in height and $1.89 \mathrm{~m}$ in width with conical shape structure was dug vertically down to the bottom to uncover the mystery. Accordingly, several queens were uncovered at different depth with various casts of termite colonies and termites of each colony diffused in cavities of all underground passages and corridors. Hence, one of the queens found at $3.20 \mathrm{~m}$ depth was selected to examine its fecundity, count, calculate and record laid eggs per minute. The fourth mound (M4) was situated at a lower place where the soil is dark brown in colour. It was 
shorter than others, $1.20 \mathrm{~m}$ in height, smaller in width, dug in the same way and two queens were found in royal cells at different depths. In view of that, the royal cell found at $1.15 \mathrm{~m}$ below the mound was selected, unearthed and taken out for measuring the size of the queen, dissect and count ovaries and observe fertility of the queen (Fig. 4). It was taken out with some soils and stretched on a transparent film in ambient environment for examinations. The queen was dissected and the inner parts were observed that it had two ovaries filled with fertilised eggs.

\section{Results}

The behaviour and life cycle of termites cover a great mystery. Accordingly, a mature termite colony has three main castes: (1) Reproductives (both the king and the queen), (2) soldiers and (3) workers including in-star larvae and alates existing at an immature level. Swarming period is the most dangerous one when millions of young females and males fly out in the evening during the spring or short after the rain through decentralised, self-organising systems of activity guided by the swarm intelligences, in which the winged males and females return to the ground and shed their wings. The royal couple lives in a royal chamber in the soil, enters the chamber and seals the opening. The queen is originally slim and winged corpuscle that develops into an amorphous shape of $6 \mathrm{~cm}$ long cream coloured body and lives in a special isolated chamber or royal cell and commonly mates with adult males (king) for fertilisation. After mating, the queen starts laying yellowish white eggs and hatch after an incubation period of 50-60 days. Freshly hatched young ones appear as tiny termites that grow without significant morphological changes (other than wings and soldier specialisations), because termites commonly undergo incomplete metamorphosis.

In all sites, it was ascertained that termite mounds are made up of different materials, which is stronger than normal soil assembly and the wall of the royal cell is made up of special materials, which is more concrete than any other chambers. Structurally, the inner part of each mound composes of various networks connected to each other via cavities and mud tubes or passages, through which termites flash for different tasks including the fungal farm, naturally made at the bottom of mounds. The vertical profile of mounds exhibited the inner structures, cavities and duties of termites: soldiers watch out nonstop on the gate of the mound alternatively putting their heads out side of the hole, workers immediately start maintaining demolished parts by making mud tubes and others diffusively rush restlessly. As soon as any danger occurs nearby, they report alarm using natural siren messages of pheromone, warn the colony and call for more soldiers to fight against. When the mound was dug, termites were annoyed and react against unknown strangers, blast quickly and pass over a siren message to other termites informing that instant measure is required to be taken right away. Workers are male and female termites, their task is to secure food, build corridors, passages (cavities) for the whole colony. Full grown workers are soft-bodied, wingless, blind, creamy white and once they are able to digest wood, the workers provide food for the entire colony. The workers undertake all the labours in the colony like food obtaining, feeding other caste members and immature groups, excavate wood and construct tunnels. They build and maintain nests with elaborated structures made of a combination of soil, mud, chewed wood or cellulose, saliva and feces to house the colony. Some species maintain fungal gardens from plant matter that provide a nutritious mycelium, on which the colony feeds and nurse nymphs that often cast off for several times in the course of development. Arboreal or underground nests of termites made by the workers 
are punctuated by a maze of tunnel like galleries that provide air conditioning, control carbon dioxide and oxygen balance and allow the termites to move through the nest. Some termite species do not have a true worker caste and instead rely on nymphs that perform the same work.

Termite soldiers are creamy white, soft-bodied, wingless and blind with enormously elongated, brownish, hard and equipped with two jaws, who must be fed by workers as they are incapable of feeding themselves until they reach maturity within a year and live up to 5 years. They are less numerous in the colony than workers, immature and marked by big heads with biting teeth and their sole function is to defend the colony against invaders and castes. They have anatomical and behavioural specialisations with strength and armour, which are primarily useful against ants attack. In some species, the soldiers bear biting teeth, which is secured in a mask-like antenna on their heads that produces protective hormones called chitin, which they use as a weapon to shot, defend, draw back and avert enemies from the colony. For evidence, even when provoked, these large soldiers of termites do not defend themselves, but retreat deeper into the mound and can attack big and strong ants forcefully and win using their population quantity. Consequently, when the mound is disturbed by any means of stranger, it was found that workers instantly start rebuilding mud tubes, the soldiers run in different directions to fight against enemies with their armored heads and strong jaws to protect the colony from danger.

Each mound consisted of dissimilar colonies of termites, although their origin is one mother (the queen) and a single mound composed of several queens in different chambers forming their own colonies dissimilar to each other in the same cast.

In all mounds, the central chamber gradually develops into passages and corridors in all directions and at the bottom of each mound; an area of $30 \mathrm{~cm}$ long is full of labyrinth fungal garden grown to feed the whole colony. In each mound, queens were found at different depths from the surface; termites were spread out in cavities and perform various labours and tasks in an iron discipline throughout $24 \mathrm{~h}$. The queen was found occupying a royal cell of an area of more than $250 \mathrm{~cm}^{2}$ composing of sizes about $10 \mathrm{~cm}$ (length), $5 \mathrm{~cm}$ (width) and $5 \mathrm{~cm}$ (height) and observed laying eggs in each time budget, workers feeding, nurse and takeaway eggs to the special protective cavities near the fungal farm. Across all colonies, stunted and winged standby females that substitute or become queens when the existing queen dies away were recorded.

In each royal cell of mounds, queens were found laying eggs at various time intervals: the first queen in M1 was distinguished to lay in each 2-3 s one egg (25 eggs per minute), the second queen in M2 was found laying in each 3 s one egg (20 eggs per minute) and the third queen in M3 was found laying eggs in each $2 \mathrm{~s}$ one egg (30 eggs per minute).

Accordingly, it is investigated that the queen in M1 could possibly lay about 36,000 eggs per day and 13,140,000 eggs per annum, the queen in M2 could possibly lay about 28,800 eggs per day and 10,512,000 eggs per annum at favourable conditions and the queen in M3 could possibly lay 43,200 eggs per day and 15,768,000 eggs per annum. On an average, termite queens of the mounds of the study site may possibly lay about 25 eggs per minute, 36,000 eggs per day and 13,140,000 eggs annually.

M4 was designated to study the structure and inner parts of the queen, so that a queen was unearthed and found out that it was a queen, which adds an extra set of ovaries, resulting in a greatly distended abdomen and increase in fecundity (Fig. 4).

In view of that, termite queens lay eggs based on the number of ovaries they have, availability of feed and the capacity of the colony workers to feed them regularly and adequately. 
T a b le 1. Record of laid eggs per queen in a time unit.

\begin{tabular}{|l|c|c|c|}
\hline Studied mounds & $\begin{array}{c}\text { M1 } \\
\text { Laid eggs/queen }\end{array}$ & $\begin{array}{c}\text { M2 } \\
\text { Laid eggs/queen }\end{array}$ & $\begin{array}{c}\text { M3 (queen) } \\
\text { Laid eggs/queen }\end{array}$ \\
\hline Time & $8: 00$ & $12: 00$ & $16: 00$ \\
\hline Day one & $24 / \mathrm{min}$ & $21 / \mathrm{min}$ & $32 / \mathrm{min}$ \\
\hline Day two & $26 / \mathrm{min}$ & $20 / \mathrm{min}$ & $30 / \mathrm{min}$ \\
\hline Day three & $25 / \mathrm{min}$ & $19 / \mathrm{min}$ & $29 / \mathrm{min}$ \\
\hline Average & $25 / \mathrm{min}$ & $20 / \mathrm{min}$ & $30 / \mathrm{min}$ \\
\hline
\end{tabular}

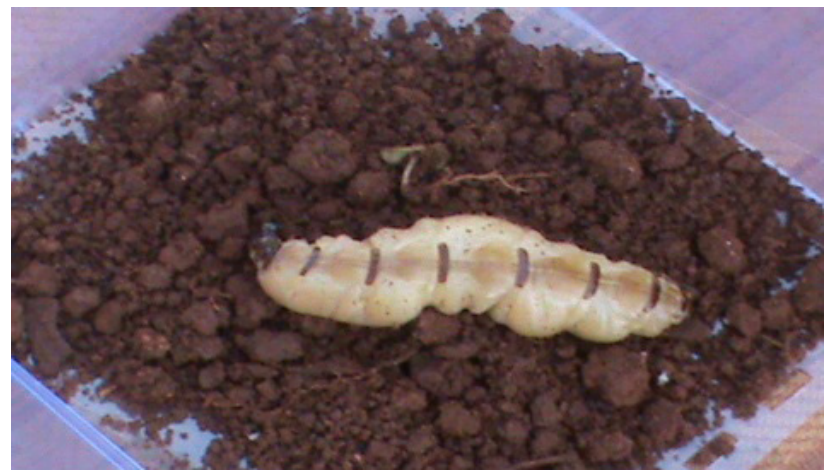

Fig. 4. Unearthed queen (Photo by Sutuma Edessa).

\section{Discussion}

Termites live deep in cavities of mounds or nests and mostly laid eggs are accumulated in a special chamber to get direct feed until they develop into imago stage. The colony of termites consists of one pair of reproductive group and a set ratio of soldiers to workers and nymphs. If members of any caste are lost, additional members develop from nymphs to restore the balance and the number of termite individuals in castes in a colony is closely regulated naturally. Both reproductive and soldier castes secrete a pheromone (chemical signal) that is transmitted through food sharing and grooming to other members of the colony and inhibits development of reproductive group or soldiers. If the caste balance of the colony is upset, some undifferentiated nymphs do not receive the pheromone message and thus develop into reproductive groups or soldiers, thereby restoring the balance.

Killing queens in mounds or nests is not a solution to eradicate termites, because the standby females from the colony may instantaneously replace the dead one within $24 \mathrm{~h}$. Conversely, if overproduction of one caste occurs, selective cannibalism restores the balance naturally. Termites have aggressive and active periods in relation to the reproduction and rise of population based on the environmental and seasonal condition. Although it was found out that termite queens of the study sites lay about 25 eggs per minute, 36,000 eggs per day and 13,140,000 eggs annually on an average, this number may change according to the conditions. According to Vagner (1987), a queen of termite lay eggs at an iron law of every 2-3 s one egg, 20-35 thousands of eggs per day and 12 million eggs annually for several years. 
Termites damage wooden materials, eat everything, live plants, grasses, litter, fossils, humus, construction objects, flesh, bones and structures (Piper, 2007). Usually, removal of vegetation cover causes changes in environmental climatic conditions that have consequences like the appearances of new types of diseases, which more or less affect humans, animals and plants. Thus, when the environment loses its substantial biological wealth, biotic ecosystems transfer into abiotic landscapes leading to removal of vegetation cover, the disappearance of species, disturbance of hydrological cycle and change of environment into desertification and disastrous conditions, in which human beings and the rest of living organisms suffer a lot. Termites often cause shortage of food, fodder, fuel energy, construction and industrial materials, death of wild life and natural resources. Additionally, owing to the translocation of various vectors and carriers, different types of calamities, drought and unfavourable living ecosystems appear or happened, which is ecologically and economically disastrous.

In order to alleviate the impact termites have on environments or to fight against, application of insecticide chemicals may be effective to certain extents, but not the best ones to be recommended due to the reason that it is disadvantageous environmentally. Neverthelles, some of the biological methods of controlling the population size and aggressiveness of termite are or barriers recommended. It is attested that red ant workers enter into the mound, rush diffusively through all cavities and collect all eggs and destroy or eat them. Red ants are the real enemies of termites and so that the soldiers perform pragmatic defending task against ants, often forcefully win and are proud to be dead for their colony.

Korensky (1974) confirms that red ants can attack termites in the statement saying "red ants are the first class enemies of termites". In view of that, one can feed red ants with meat and settle a damp of ants near the mounds or nests of termites and continuously march ants against termites to devastate them through time.

Aardvarks or Earth pigs (nocturnal animals) that are widely distributed all over Ethiopia including the study site can be used against termites. They begin searching for termites at night and capable to dig very deep into the hard soil and hunt for termite, as they are designated as insect hunter animals or termite-eaters using their thin and very long tongues to collect termites and consume as major sources of food.

Defensive plants could be applied against termites, which is typically achieved by secreting anti-feeding chemicals (such as oils, resin and lignin) into the woody cell walls. Many of the strongly termite-resistant tree species have heartwood timber, which is extremely dense due to accretion of resins that reduces the ability of termites to efficiently digest the cellulose like the Eucalyptus, Turpentine (Pines) and Teak or one of the Sequoias are recommendable to defend termites (Abe et al., 2002). Neem trees are useful repellent in imposing negative influence on activities, lifecycle and population of termites due to the reason that they contain special properties, which can affect the lifecycle of insects (Ruskin, 1992).

\section{Conclusion}

The lifecycle of termites is amazing. The queen with several ovaries can lay eggs for several years in each 2-4s on an average and the colony functions all naturally given duties nonstop throughout $24 \mathrm{~h}$. Termite soldiers are usually blind, but in some families, particularly among 
the damp wood termites, soldiers may develop at least partly functional eyes (Shellman-Reeve, 1997). Communication of termites to the outside world is a narrow and small passage, through which the workers continually come to feed the queen, nurse and take away laid eggs.

Ecologically, termites have both negative and positive impacts. The positive advantages are that they are helpful in decomposing hard soil and let air to enter deep in the ground for further decomposition, nutrient recycling and create favourable shelter or habitat for reptiles and others by building mounds either above ground or deep into the ground. Larger termite mounds also provide habitats for animals specifically on plains in Africa that are seasonally inundated by a rainy season for smaller animals, birds, scorpion, lizards, snakes and the like. Some authors reported that people have eaten termites in many cultures throughout parts of Asia, America and Africa and are sources of diet and can replace the future food.

As the negative effect of termites outweighs the positive effect, minimising the population is important for human beings.

\section{References}

Abe, T., Bignell, D.E. \& Higadhi M. (2002). Termites: evolution, sociality, symbiosis, ecology. Dordrecht: Kluwer Academic Publishers.

Becker, G. (1976). Concerning termites and wood (in Spain). Unasylva, 28(111).

Breznak, J.A. \& Brune A. (1994). Role of microorganisms in the digestion of lignocelluloses by termites. Ann. Rev. Entomol., 39, 453-487. DOI: 10.1146/annurev.en.39.010194.002321.

Carpenter, L.P. (1967). Microbiology. Philadelphia, London: W.S. Saunders Company.

Donovan, S.E., Jones, D.T., Sands, W.A. \& Eggleton P. (2000). Morphological phylogenetics of termites (Isoptera). Biol. J. Linn. Soc., 70, 467-513. DOI: 10.1111/j.1095-8312.2000.tb01235.x.

Duur, K.A., Eggleton, P., Rouland-Lefevre, C., Guldberg-Frǿslev, T., Rosendahl, S. \& Boomsma J.J. (2002).The evolution of fungus-growing termites and their mutualistic fungal symbionts. Proc. Natl. Acad. Sci. USA, 99(23), 14887-14892. DOI: 10.1073/pnas.222313099.

Eggleton, P. (2000). Global patterns of termite diversity. In T. Abe, D.E. Bignell \& M. Higashi (Eds.), Termites: evolution, sociality, symbioses and ecology (pp. 25-51). Dordrecht: Kluwer Academic Publishing.

Eggleton, P. \& Tayasu I. (2001). Feeding groups, life types and the global ecology of termites. Ecol. Res., 16(5), 941-960. DOI: 10.1046/j.1440-1703.2001.00444.x.

Emerson, A.E. (1952). The biogeography of termites. Bull. Am. Mus. Nat. Hist., 99, 217-225.

Engel, M.S. \& Krishna K. (2004). Family-group names for termites (Isoptera). Am. Mus. Novit., 3432(1), 1- 9. DOI: 10.1206/0003-0082(2004)432<0001:FNFTI 2.0.CO;2.

Grimaldi, D. \& Engel M.S. (2005). Evolution of insects. Cambridge: Cambridge University Press.

Hunt, J.H. \& Nalepa C.A. (1994). Nourishment and evolution in insect societies. Boulder: Westview Press.

Korensky, J. (1974). Afrika, kulturní obrázky z celého zemědílu. Praha: Svoboda.

Piper, R. (2007). Extraordinary animals: An encyclopedia of curious and unusual animals. Westport: Greenwood Press.

Ruskin, F.R. (1992). Neem, a tree for solving global problems. Washington: NAP.

Shellman-Reeve, J.S. (1997). The spectrum of eusociality in termites. In The evolution of social behavior in insects and arachnids (pp. 52-93). Cambridge: Cambridge University Press. DOI: 10.1017/CBO9780511721953.005.

Ulrich, G.M. \& Nicole G. (2002). Fungus-farming insects: Multiple origins and diverse evolutionary histories. Proc. Nat. Acad. Sci. USA, 99(24), 15247-15249. DOI:10.1073/pnas.242594799.

Vagner, J. (1987). Afrika, život a smrt zvířat. Praha: Svoboda. 